\title{
Apresentação - A fenomenologia da vida de Michel Henry e a psicologia clínica
}

\author{
Andrés Eduardo Aguirre Antúnez ${ }^{\mathrm{a}}$ \\ Florinda Martins ${ }^{\mathrm{b}}$ \\ Maristela Vendramel Ferreira ${ }^{a}$ \\ aUniversidade de São Paulo, Instituto de Psicologia. São Paulo, SP, Brasil \\ bUniversidade Católica Portuguesa. Porto, Portugal
}

A fenomenologia, segundo Michel Henry, acederá às coisas mesmas se puder atender à fenomenalidade da Vida em seu viver, pois acedemos à fenomenalidade da Vida ao compreendermos o seu enredo em nosso viver. Um enredo que nos abre de imediato porque originariamente, ao outro: outro que se dá como vida que provamos em afeção constitutiva de nós mesmos. A primordialidade do fenômeno é, assim, relacionalidade, pelo que trazer para o âmbito da fenomenologia da vida um projeto de investigação interdisciplinar é tarefa decorrente da própria fenomenalidade dos fenômenos. $\mathrm{O}$ projeto em rede internacional $O$ que pode um corpo?, coordenado cientificamente por Florinda Martins, da Universidade Católica Portuguesa, responde a essa exigência da fenomenalidade da vida, e tem contribuído de modo ímpar para a medicina psiquiátrica, psicanálise, psicologia clínica e as neurociências.

A partir de conferências, apresentações de trabalhos em disciplinas de pós-graduação, graduação e curso de difusão em cultura e extensão, realizados no Instituto de Psicologia da USP em 2013, apresentamos os resultados da integração interdisciplinar entre filósofos e psicólogos desenvolvidos na USP - trabalhos também apresentados no Colóquio Internacional Michel Henry ocorrido na Universidad Nacional General Sarmiento, Buenos Aires, sob a coordenação de Mario Lipsitz - na forma de um projeto de dossiê com cinco artigos.

Estes trabalhos fazem o levantamento do histórico do desenvolvimento internacional sobre a obra de Michel Henry a respeito das problemáticas médicas e psicológicas, bem como apresentam os resultados das investigações por nós realizadas e publicadas em 2014 pela Editora Escuta sob o título: A fenomenologia da vida de Michel Henry: interlocução entre filosofia e psicologia, com autores de Portugal, Brasil, França e Bélgica, e sob a organização de Andrés Antúnez, Florinda Martins e Maristela Vendramel Ferreira, e reconhecimento do Fonds Michel Henry.

No dossiê que agora apresentamos, mostramos que, com o princípio do retorno às coisas mesmas, se abre à fenomenalidade do corpo uma dimensão que o vincula à vida, vivificando-o das entranhas à flor da pele, resultando que é na vida concreta que os saberes, nomeadamente os saberes científicos, ganham corpo e podem ir de encontro às questões que, na clínica ou na terapêutica, se colocam. Isto é, a vida de todos e de cada um de nós é uma vida encarnada: a pessoa não é um conceito abstrato, nem o corpo é um acidente da alma.
Por conseguinte, na fenomenologia da vida se rompe o estatuto de indeterminabilidade do corpo - "com efeito ninguém até agora determinou o que pode um corpo" (Espinosa, Ética, III, prop. II. Schol.1) - porquanto uma vida encarnada é sempre uma vida que sente, a cada vez, uma tonalidade afetiva que a singulariza e, ao mesmo tempo, nela se rompe o mutismo da subjetividade, porque uma vida encarnada é uma vida em que o outro, ao dar-se como afeto, se dá na intimidade constitutiva do sentimento.

\section{Os artigos}

Andrés Antúnez analisa e apresenta a temática que viabilizou o histórico da feliz união entre fenomenologia da vida e medicina. Em uni-las está a necessidade de atendermos aos fenômenos que tecem uma humanologia, pois é neles que se fundam os processos terapêuticos de que a medicina, mesmo na vertente psiquiátrica, é apenas uma modalidade. Para Andrés Antúnez, o nosso enredo na vida revela-nos a nós mesmos ao mesmo tempo que nos revela o outro do nosso afeto. Assim, a fenomenalidade do sentimento é reveladora do nosso agir, e enquanto tal é portadora de uma valoração ética. É pelo agir, pelo nosso enredo na e com a vida, que com ela nos destinamos: em propriedade de nós, coproprietários da vida: na autenticidade de nós, a autenticidade de outrem. Mostra também as relações entre Fenomenologia da Vida e a clínica.

E como o agir se processa num corpo dotado de sentidos que nos abre à vida e aos outros, Benoît Kanabus chama, no seguimento de Michel Henry e de Christophe Dejours, tais fenômenos de propriedade de si na copropriedade da vida, fenômenos de corpopropriação. Dentre esses fenômenos, Benoît Kanabus especifica as relações laborais como relações de corpopropriação, e dentre estas especifica ainda o trabalho do psicoterapeuta. O processo terapêutico pressupõe que a afeção da vida em nós e a nossa adesão ao afeto implicam-se, mas não nos dispensam do processo. A sua revisão da entrevista com Dejours - que pelo menos desde 1996 trabalha a relação entre Fenomenologia da Vida e ergoterapia - é um artigo original que traz aspectos fecundos para a clínica psicoterápica e psicanalítica e suas relações com a fenomenologia de Michel Henry.

Nesse sentido, o nosso enredo na vida não é opção nossa, mas uma exigência inerente ao viver. Exigência que transporta em si dificuldades para as quais nem sempre encontramos solução, e que estão na origem dos fenômenos ditos patológicos. Maristela 
Vendramel Ferreira estuda as implicações e possibilidades dos fenômenos de corpopropriação em pessoas com degenerações no corpo, especificamente com distúrbios da audição. No contexto da fenomenologia, as afeções da vida, nas suas manifestações ditas orgânicas, fazem parte integrante do paciente, sendo, portanto, a partir delas, na positividade da sua doação, que o psicoterapeuta pode interagir com o paciente. Mas isso levanta uma questão: poderão essas partes orgânicas não corpopropriadas ser denominadas desencarnações da vida?

Se não sabemos ainda como chamar as estas afeções constitutivas de cada um de nós, afeções que interferem com o nosso enredo com a vida em nós e nos outros por nos desesperarem das entranhas à flor da pele, sabemos todavia que a compreensão do modo como na vida se efetuam contribuiu para o sucesso dos fenômenos de corpopropriação.

Assim, há que repensar a relação da filosofia com as ciências da vida, incluindo a biologia, as neurociências e afins. É o que faz Florinda Martins ao dar-nos contas do diálogo que tem desenvolvido com a investigadora em neurociências, Cátia Teixeira. A interrogação sobre os métodos usados põe em causa as usuais distinções entre objetividade e subjetividade, uma vez que as duas dimensões são pressupostas pelo método científico. Este, ao introduzir na sua linguagem a palavra "expressão" da afeção da vida, usa o mesmo conceito que a fenomenologia para superar a distinção objetividade versus subjetividade. Por outro lado, as implicações de algumas dessas investigações, no caso sobre a memória, na qualidade de vida de cada paciente, mostram a íntima articulação entre saber fazer e ética, aproximando-se das intuições mais originais do texto de Michel Henry A ciências e a ética (1992/2010), em que ética se identifica com bem saber fazer, anulando assim, nele, as controvérsias e as polêmicas que não passam de lugares comuns no universo das relações entre ciência e filosofia.

Todavia, em humanologia, a importância do diálogo interdisciplinar não se esgota em si mesmo. Eles são um saber que, no dizer de Andrés Antúnez, não dispensa a inventividade do terapeuta no processo de relação com o paciente. E é para a importância da inventividade no processo terapêutico que Gilberto Safra chama a atenção: ao acompanhar o desenvolvimento destes trabalhos, reconheceu nas diversas indagações sobre o sofrimento e inquietações do humano a necessidade de fundamentar as situações clínicas em perspectivas não só racionalistas e epistemológicas, mas clínicas e éticas, acolhedoras da experiência humana. $\mathrm{O}$ autor, a partir de situações clínicas, reconhece a importância da interdisciplinaridade a partir da fenomenologia da vida e sua contribuição para a prática clínica na atualidade.

Pelo trabalho interdisciplinar aqui apresentado, este dossiê, inteiramente inovador em termos de processo de trabalho interdisciplinar, provoca a nossa investigação.

\section{Referências}

Antúnez, A. E. A., Martins, F., \& Ferreira, M. V. (2014).

Fenomenologia da vida de Michel Henry: interlocuções entre filosofia e psicologia. São Paulo, SP: Escuta.

Espinosa, B. de (1965). Ética, III, prop. II, Schol.1. Paris: Flammarion.

Henry, M. (2010). As ciências e a ética (F. Martins, trad.). Covilhã, Portugal: LusoSofia. (Trabalho original publicado em 1992) 